\title{
The Impact of Job Satisfaction on Organizational Commitment Among Generation Y Healthcare Employees
}

\author{
Gülfer Bektaş ${ }^{1}$ (D) , Volkan Mısırlıoğlu² (iD , Emre İşçi ${ }^{3}$ (iD
}

${ }^{1}$ Acibadem Mehmet Ali Aydinlar University, Faculty of Health Sciences Department of Healthcare Management, Istanbul, Turkey

${ }^{2}$ Acibadem Healthcare Group Centre of Research and Development, Istanbul, Turkey

${ }^{3}$ Marmara University, Faculty of Health Sciences Department of Healthcare Management, Istanbul, Turkey

Gülfer BEKTAŞ

Volkan MISIRLIOĞLU

Emre işçi

\section{Correspondence: Gülfer Bektaş} Acibadem Mehmet Ali Aydinlar University, Faculty of Health Sciences Department of Healthcare Management, Istanbul, Turkey Phone: +902165004192

E-mail: gulfer.bektas@acibadem.edu.tr

\begin{abstract}
Objective: This study reported on the knowledge on the factors impacting job satisfaction and organizational commitment in the healthcare sector. It critically examined the relationship between job satisfaction and organizational commitment among Generational Y healthcare workers.

Methods: The study involved 236 healthcare professionals working in a private healthcare group in Istanbul, The primary method of data collection was a questionnaire composed of three sections. The first section recorded data concerning participants' demographic information. The second and third sections aimed to assess the participant's job satisfaction and organizational commitment by applying the Minnesota Job Satisfaction scale and the Organizational Commitment scale developed by Meyer and Allen. In data analysis and evaluations, frequency tables, central and prevalence criteria, Pearson's correlation test and simple linear regression analysis were employed and analysed in the SPSS 20 statistical package program.

Results: 0 f 236 healthcare workers, $49.4 \%$ of the participants expressed that they have been working in the organization for 1 to 5 years. Among those healthcare workers who belonged to generation $\mathrm{Y}$, a significant and positive relationship was found between job satisfaction and organizational commitment $(r=0.719, p=0.000)$.

Conclusion: Our study results demonstrated a positive and significant relationship between job satisfaction and their organizational commitment among Generation $Y$ healthcare workers. Among the factors identified, it was observed that pecuniary and moral support received by employees have increased the perception of job satisfaction, whereas economic security and rewards associated with the employment strengthened organizational commitment. The study discussed human resources practices that will strengthen job satisfaction and organizational commitment.
\end{abstract}

Keywords: Job satisfaction, generation Y, organizational commitment

\section{Y Kuşağı Sağlık Çalışanlarında İ̧ Doyumunun Örgütsel Bağlıı̆̆a Etkisi}

ÖZET

Amaą: Bu çalışmada sağlık sektöründe iş tatmini ve örgütsel bağlılı̆ı etkileyen faktörler hakkında bilgi verilerek Y kuşağı sağık çalışanlarııın iş doyumu ile örgütsel bağılıkları arasındaki ilişkinin incelenmesi amaçlanmıştır

Yöntem: Araştırma, istanbul ilinde faaliyet gösteren ve kolayda örnekleme yoluyla belirlenen bir özel grup hastanesinde gerçekleştirilmiş̧̦ir. Araştırmanın örnekleminde, araştırmaya katılmayı kabul eden 236 çalışan yer almaktadır. Araştırmada veri toplama aracı olarak anket uygulanmıştır. Üç bölümden oluşan anketin ilk bölümünde katllımcların demografik bilgilerine ilişkin veriler kaydedilmiştir. İkinci ve üçüncü bölümlerde, Minnesota Iş̧ Doyum Ölç̧eği le Meyer ve Allen tarafindan geliştriilen Örgütsel Bağ|lık Ölçeği uygulanarak katılımcıların iş tatmini ve örgütsel bağ|ıkklarının değerlendirilmesi amaçlanmışıı. Veriler elektronik ortama aktarılarak, SPSS 20 istatistik paket programında analiz edilmiştir. Analiz ve değerlendirmelerde sıklık tabloları, merkezi ve yaygınlık ölçütleri, Pearson korelasyon testi ve basit doğrusal regresyon analizleri kullanıımıstır.

Bulgular: 236 sağlık çalışanııın \%49,4'ü kurumda 1 ila 5 yıldır çalışı̆ı̆ııı ifade etmiştir. Elde edilen bulgulara göre, Y kuşağı sağlık çalışanlarının iş doyumları ile örgütsel bağılıkları arasında istatiksel olarak pozitif yönde kuvvetli, anlamlı ilişki bulunmuştur $(r=0.719$, $\mathrm{p}=0.000$ ).

Sonuç: Araştırma sonuçları Y Kuşağı sağlık çalışanları arasında iş tatmini ile örgütsel bağllıkları arasında pozitif ve anlamlı bir ilişki olduğunu göstermiştir. Belirlenen faktörlerden çalışanların aldığı maddi ve manevi desteğin iş tatmini algııını artırdığı, ekonomik güvence ve istihdamla bağlantılı ödüllerin ise örgütsel bağllığı güçlendirdiği görülmüştür. lş̧ tatmini ve örgütsel bağllığı güçlendirecek insan kaynakları uygulamaları ele alınarak tartışıııştır.

Anahtar Kelimler: İ̧ doyumu, Y kuşağı, örgütsel bağllıkk 
ob satisfaction and organizational commitment of employees are considered important issues for hospital administrators in human resources management. The determination of levels of job satisfaction and organizational commitment in a hospital also yields to important findings on their effects on hospital performance, efficiency, employee productivity and quality of patient care $(1,2)$. In the literature, the relationship between organizational commitment and job satisfaction is described as a two-way relationship, meaning the concepts are both their antecedents and consequences $(3,4)$. High levels of job satisfaction and organizational commitment are associated with more positive work outcomes, whereas low levels are perceived to lead to poor organizational performance (5). Such findings support the current trend in human resources management in healthcare industry for the creation of work environments where greater organizational commitment and high levels of job satisfaction and organizational commitment of healthcare employees can be achieved.

There are multiple definitions of job satisfaction in business literature (6). The most prevalent definition by Locke (1976) describes job satisfaction as 'a pleasurable or positive emotional state resulting from the appraisal of one's job or job experiences' (7). Hulin, Judge and Klinger (2003) attribute three multidimensions to job satisfaction, including cognitive, emotional and behavioural components $(8,9)$. The concept of job satisfaction reflects the employee's reaction to the job itself or to certain aspects of the job (10). On the other hand, organizational commitment is an employee's strong desire to remain a member of a certain organization, the belief in and adoption to the organization's values and goals, and the willingness to strive for effectiveness and success on behalf of the organization $(11,12)$.

Low levels of job satisfaction and organizational commitment may have adverse impact on the overall performance in hospitals including the quality of healthcare, patient loyalty and the profitability of hospitals (13). Management practices in hospitals are often cited as factors leading to such low levels. Healthcare employees who feel undervalued, neglected, disregarded, unappreciated and excluded from decision making processes have reported greater dissatisfaction (14). A systematic review of the levels of job satisfaction and organizational commitment should be carried out by hospital administrations in order to detect declining levels in existing working practices and put in place necessary administrative and policy tools (15).
Workforce in hospitals is increasingly composed of employees from three generations. Generations possess their own unique experiences, expectations and values that require special attention from a human resources perspective (16). Managers and leaders should also analyse intergenerational approach differences in evaluating levels of job satisfaction and organizational commitment (17).

Members of Generation Y born between 1980 and 2000 make up 35\% of the total population in Turkey. Qualities associated with Generation $Y$ are optimism, high level of confidence, entrepreneurial approach and technology savviness $(18,19)$. It is observed that members of Generation $Y$ can combine collaboration and teamwork and prefer to behave freely while doing their job, to do it in their own way and to be flexible in all matters (18, 19). They also have expressed a preference for quick feedback and reward processes (20). Managers and hospital administrators are advised to adopt working practices and policy and administrative tools in order to maintain high level of organizational commitment and loyalty of employees. Such practices include flexible working hours, trainings on recent technologies, frequent feedback mechanisms and a strong communication network (20).

In the process of evaluating healthcare employees' levels of job satisfaction and organizational commitment, managers and administrators in hospitals should consider a variety of factors and issues including pay and benefits, nature of the job, existence of a communication network, structure of decision-making processes as well as hospital culture, educational level and quality of management. It is increasingly important for managers to undertake this evaluation taking into account of the needs of new generation entering into workforce. The aim of the present study is to focus on the perceptions of Generation $Y$ healthcare employees and assess whether a substantive relationship exists between levels of job satisfaction and organizational commitment. The study also seeks to determine whether variables such as gender, educational level, length of employment within the hospital, length of employment within profession, job title, nature of shifts and gender of manager substantively affect job satisfaction and organizational commitment. The indicators and factors affecting job satisfaction and organizational commitment can be incorporated into the managements' strategic human resources planning and adaptation in Turkey. Thereby, hospitals and healthcare management can better be prepared to accommodate and integrate Generation $Y$ employees into their workforce. 


\section{Methods}

\section{Design and sample}

This cross-sectional study was conducted at a private hospital operated by a healthcare group located in Istanbul, Turkey from December 10, 2019 to January 10, 2020. Out of the 305 employees who received the questionnaire, 236 healthcare employees participated in the study. The study used a questionnaire with three main sections. The first section collected demographic data on gender, educational level, length of employment within the hospital length of employment within profession, job title, nature of shifts and gender of manager.

The study protocol was approved by the Acıbadem University and Acıbadem Health Institutions Medical Investigation Ethics Committee (December 5, 2019; No. 2019-19/34). The study was conducted in accordance with the principles of the Declaration of Helsinki. In addition, each participant provided written informed consent to participate in the study.

\section{Instrumentation}

The organizational commitment levels of participants were assessed using the Organizational Commitment Scale created by Meyer and Allen (21). The scale evaluated participants' attitudes on topics such as the option to leave organization, the feelings of belonging and gratitude, and the relationship with superiors. Participants were asked to choose an option that best aligned with their views. Responses were recorded using a five-point Likert scale, scored as 1: Strongly disagree, 2: Disagree, 3:Undecided, 4: Agree, 5: Strongly agree. Scores closer to 1 stand for lower levels of organizational commitment, whereas scores closer to 5 illustrate higher levels of organizational commitment. The internal reliability coefficient of the scale was found to be less than 0.70 . This indicates a reliable level of internal value (Cronbach alfa $>0,70$ ).

The job satisfaction levels of participants were assessed using the Minnesota Job Satisfaction Scale developed by Weiss, England, David and Lofguist (22). The statements assessing job satisfaction levels were based on factors such as salary, working conditions, opportunities for promotion, flexible working, participation and feedback. Responses from participants were recorded using a fivepoint Likert scale, termed 1: Strongly disagree, 2: Disagree, 3:Undecided, 4: Agree, 5: Strongly agree. Scores closer to 1 stand for lower levels of job satisfaction, whereas scores closer to 5 illustrate higher levels of job satisfaction. The internal reliability coefficient of the scale was likewise found reliable (Cronbach alfa $>0,70$ ).

\section{Data analysis}

The data was analysed using SPSS (Statistical Package for Social Sciences, version 18.0). In the calculation of job satisfaction and organizational commitment scores: credibility, correlation and simple regression analysis were used. Our descriptive data was expressed in mean \pm standard deviation (SD), median (min-max), or number and frequency tables. Pearson coefficient and simple regression analysis was employed to test the relationship between job satisfaction and organizational commitment. A p value of $<.05$ was considered statistically significant.

\section{Results}

This section discusses the study findings by reference to tables and figure derived from our statistical analyses.

Table 1 demonstrates demographic data of participants. Of the 235 participants, the majority of participants were women $(176,74.9 \%)$ and medical secretaries/patient relations officers $(93,40.97 \%)$. The remaining participants were nurses $(53,23.35 \%)$, physicians $(16,7.05 \%)$, midwives $(0.44 \%)$, laboratory assistants $(0.88 \%)$, healthcare staff $(1.76 \%)$ and others. $50(21.4 \%)$ of the participants held a high school diploma; 75 (32.4\%) graduated from an associate degree program; 85 (36.3\%) graduated from college; 19 (8.1\%) had a master's degree; and five participants (2.1\%) had a doctorate degree.

Among all participants, the length of time spent in the profession ranged from 1 to more than 16 years. Of the 231 participants, 19 (8.1\%) worked for less than a year, 114 (49.4\%) worked between 1-5 years; 63 (27.3\%) for 6-10 years; 27 (11.7\%) for $11-15$ years; and 8 (3.5\%) for more than 16 years. In relation to the number of years spent in current workplace, $112(62.9 \%)$ worked for $0-5$ years; $48(27.0 \%)$ for $6-10$ years; $10(5.6 \%)$ for $11-15$ years; three $(1.7 \%)$ for $16-20$ years; and five $(2.8 \%)$ for 21 years and above. Similarly, regarding the number of years spent in the current workplace, 113 participants $(48.3 \%)$ noted that they worked in the current workplace for 1-5 years, $49(21 \%)$ for $6-10$ years, 52 (22.3\%) for less than a year, 18 $(7.7 \%)$ for $11-15$ years and one participant $(0.4 \%)$ worked for more than 16 years. Most participants reported that they worked shifts in daytime $(72.53 \%)$, while 16 worked only night-time shifts $(16 \%)$ or rotated between both (20.60\%). Majority of the participants $(61.5 \%)$ reported they had female managers, while $38.5 \%$ took orders from male managers. 


\begin{tabular}{|c|c|c|c|}
\hline & & f & $\%$ \\
\hline \multirow{2}{*}{ Gender } & Female & 176 & 74.9 \\
\hline & Male & 59 & 25.1 \\
\hline Total & & 235 & 100 \\
\hline \multirow{5}{*}{ Education level } & High school & 50 & 21.4 \\
\hline & Associate degree & 75 & 32.1 \\
\hline & College & 85 & 36.3 \\
\hline & Master's & 19 & 8.1 \\
\hline & $\mathrm{PhD}$ & 5 & 2.1 \\
\hline Total & & 234 & 100 \\
\hline \multirow{5}{*}{$\begin{array}{l}\text { Length of employment within the } \\
\text { profession (years) }\end{array}$} & $<1$ year & 19 & 8.1 \\
\hline & $1-5$ years & 114 & 49.4 \\
\hline & 6-10 years & 63 & 27.3 \\
\hline & $11-15$ years & 27 & 11.7 \\
\hline & $>16$ years & 8 & 3.5 \\
\hline Total & & 231 & 100 \\
\hline \multirow{5}{*}{$\begin{array}{l}\text { Length of employment within the } \\
\text { hospital (years) }\end{array}$} & $<1$ year & 52 & 22.3 \\
\hline & $1-5$ years & 113 & 48.5 \\
\hline & 6-10 years & 49 & 21 \\
\hline & $11-15$ years & 18 & 7.7 \\
\hline & $>16$ years & 1 & 0.4 \\
\hline Total & & 233 & 100 \\
\hline \multirow{3}{*}{ Shift patterns } & Day & 169 & 72.53 \\
\hline & Night & 16 & 6.87 \\
\hline & Day-Night & 48 & 20.60 \\
\hline Total & & 233 & 100 \\
\hline \multirow{9}{*}{ Job title } & Nurse & 53 & 23.35 \\
\hline & Healthcare staff & 4 & 1.76 \\
\hline & Midwife & 1 & 0.44 \\
\hline & Physician & 16 & 7.05 \\
\hline & Laboratory assistant & 2 & 0.88 \\
\hline & Emergency technician & 8 & 3.52 \\
\hline & X-ray technician & 1 & 0.44 \\
\hline & $\begin{array}{l}\text { Medical secretary/Patient relations } \\
\text { officer }\end{array}$ & 93 & 40.97 \\
\hline & Other & 49 & 21.59 \\
\hline Total & & 227 & 100 \\
\hline \multirow{2}{*}{ Gender of manager } & Female & 144 & 61.5 \\
\hline & Male & 90 & 38.5 \\
\hline Total & & 234 & 100 \\
\hline
\end{tabular}


Table 2 illustrates the result of the Pearson correlation test between job satisfaction and organizational commitment among Generation $Y$ healthcare employees. Accordingly, out of the 235 healthcare employees, Table 2 illustrates the average score for job satisfaction $(X=3.55)$ and for organizational commitment $(X=3.48)$. According Alpar (2011), a finding of the correlation coefficient ( $r$ ) greater than 0.4 showed a "mid-level relationship", greater than 0.7 reveals a "strong (high relationship) and greater than 0.9 demonstrates a "very strong relationship" (Alpar, 2011). In this study, we observed a mid-level relationship between all variables $(r>0.4)$.
Table 3 provides the variance values between the variables, namely job satisfaction (predictive variable) and organizational commitment (predicted variable). There was a statistically significant relationship between job satisfaction and organizational commitment $(\mathrm{R}=0.719, \mathrm{R} 2=0.517)$.

Table 4 contains the result of the simple regression model assessing the significance of the relationship between the variables. It found that job satisfaction positively affects organizational commitment $(B=0,657, t=15,794, p<0,05)$. As $p$ value here is less than $0.05(p=0.00)$, this demonstrates the statistical significance of the $R$ value at $R=0.719$.

\begin{tabular}{|c|c|c|c|c|c|c|c|c|}
\hline & & $\begin{array}{l}\text { Intrinsic } \\
\text { Sat. }\end{array}$ & $\begin{array}{l}\text { Extrinsic } \\
\text { Sat. }\end{array}$ & $\begin{array}{c}\text { Overall } \\
\text { Sat. }\end{array}$ & $\begin{array}{l}\text { Emotional } \\
\text { connection }\end{array}$ & $\begin{array}{l}\text { Continual } \\
\text { connection }\end{array}$ & $\begin{array}{c}\text { Normal } \\
\text { connection }\end{array}$ & Overall Con. \\
\hline \multirow{4}{*}{ Intrinsic Sat. } & $r$ & 1 & .832 & .950 & .589 & .577 & .611 & .683 \\
\hline & $\mathrm{p}$ & & .000 & .000 & .000 & .000 & .000 & .000 \\
\hline & $\mathrm{N}$ & 235 & 235 & 235 & 235 & 235 & 235 & 235 \\
\hline & $\dot{x}$ & 3.72 & & & & & & \\
\hline \multirow{4}{*}{ Extrinsic Sat. } & $r$ & .832 & 1 & .964 & .557 & .607 & .643 & .693 \\
\hline & $\mathrm{p}$ & .000 & & .000 & .000 & .000 & .000 & .000 \\
\hline & $\mathrm{N}$ & 235 & 235 & 235 & 235 & 235 & 235 & 235 \\
\hline & $\dot{x}$ & & 3.39 & & & & & \\
\hline \multirow{4}{*}{ Overall Sat. } & $r$ & .950 & .964 & 1 & .597 & .619 & .656 & .719 \\
\hline & $\mathbf{p}$ & .000 & .000 & & .000 & .000 & .000 & .000 \\
\hline & $\mathbf{N}$ & 235 & 235 & 235 & 235 & 235 & 235 & 235 \\
\hline & $\dot{\mathbf{x}}$ & & & 3.55 & & & & \\
\hline \multirow{4}{*}{ Emotional Con. } & $r$ & .589 & .557 & .597 & 1 & .484 & .669 & .839 \\
\hline & $\mathrm{p}$ & .000 & .000 & .000 & & .000 & .000 & .000 \\
\hline & $\mathrm{N}$ & 235 & 235 & 235 & 235 & 235 & 235 & 235 \\
\hline & $\dot{x}$ & & & & 3.76 & & & \\
\hline \multirow{4}{*}{ Continual Con. } & $r$ & .577 & .607 & .619 & .484 & 1 & .734 & .840 \\
\hline & $\mathrm{p}$ & .000 & .000 & .000 & .000 & & .000 & .000 \\
\hline & $\mathrm{N}$ & 235 & 235 & 235 & 235 & 235 & 235 & 235 \\
\hline & $\dot{x}$ & & & & & 3.35 & & \\
\hline \multirow{4}{*}{ Normal Con. } & $r$ & .611 & .643 & .656 & .669 & .734 & 1 & .923 \\
\hline & $\mathrm{p}$ & .000 & .000 & .000 & .000 & .000 & & .000 \\
\hline & $\mathrm{N}$ & 235 & 235 & 235 & 235 & 235 & 235 & 235 \\
\hline & $\dot{x}$ & & & & & & 3.33 & \\
\hline \multirow{4}{*}{ Overall Con. } & $\mathbf{r}$ & .683 & .693 & .719 & .839 & .840 & .923 & 1 \\
\hline & $\mathbf{p}$ & .000 & .000 & .000 & .000 & .000 & .000 & \\
\hline & $\mathbf{N}$ & 235 & 235 & 235 & 235 & 235 & 235 & 235 \\
\hline & $\dot{\mathbf{x}}$ & & & & & & & 3.48 \\
\hline
\end{tabular}


Table 3. The Amount and Total Explained Variance Value of the Relationship between Variables

\begin{tabular}{|c|c|c|c|c|}
\hline Model & $\mathrm{R}$ & $\mathrm{R}^{2}$ & Adjusted $\mathrm{R}^{2}$ & $\begin{array}{c}\text { Standard } \\
\text { Error of the } \\
\text { Estimate }\end{array}$ \\
\hline 1 & .719 & .517 & .515 & .51586 \\
\hline
\end{tabular}

Table 4. Simple Linear Regression Analysis Results of Job Satisfaction and Organizational Commitment Scores

\begin{tabular}{|c|c|c|c|c|c|}
\hline & \multicolumn{2}{|c|}{$\begin{array}{c}\text { Non-standardized } \\
\text { coefficients }\end{array}$} & $\begin{array}{c}\text { Standardized } \\
\text { coefficients }\end{array}$ & \multirow{2}{*}{ t } & p \\
\cline { 2 - 4 } & $\mathbf{B}$ & $\begin{array}{c}\text { Standard } \\
\text { error }\end{array}$ & Beta & & \\
\hline Constant & 1.145 & .152 & & 7.555 & .000 \\
\hline $\begin{array}{c}\text { Job } \\
\text { Satisfaction }\end{array}$ & .657 & .042 & .719 & 15.794 & .000 \\
\hline
\end{tabular}

Dependent Variable $=$ Organizational Commitment

Table 4 also provides the parameters associated with the simple regression model (constant, regression coefficient, beta values, t-test result for the significance of the regression coefficient). It was observed that fifty-two percent of the total variance in relation to the participants organizational commitment was explained by the participant's job satisfaction. The resulting linear regression model was as the following (Figure 1):

Organizational Commitment $(Y)=1,14+0,66 *$ Job Satisfaction $(X)$

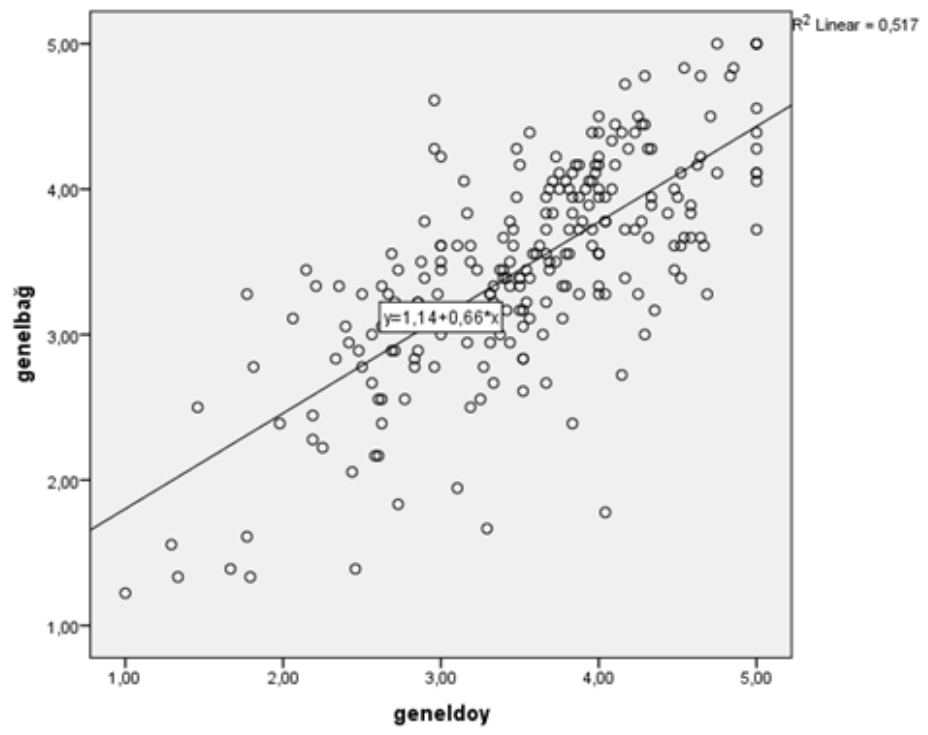

Figure 1. Scatter Plot Relation between General Commitment (X-axis) and Overall Satisfaction ( $Y$-axis)

\section{Discussion}

Healthcare organizations are institutions that embody a high level of personnel diversity and professionalization. In this light, the concepts of job satisfaction and organizational commitment are among key factors in managing team dynamics in a workforce. The hospital administrations should develop a holistic approach to topics such as job satisfaction, organizational commitment, and organizational trust. The introduction of policies aimed at improving and enhancing these concepts among the workforce will likewise be important for maintaining work productivity.

The purpose of our study was to determine the relationship between job satisfaction and organizational commitment among Generation $Y$ healthcare employees in Turkey. It sought to detect problems arising from intergeneral differences and, in turn, offer solutions to some widespread problems.

Significantly, the study concluded that the levels of job satisfaction levels among healthcare employees positively impacted organizational commitment and this relationship was strong $(r=0,719 ; p<0,05)$ (Table 3). Our findings in the regression analysis based on the factors above determined that job satisfaction positively affects the level of organizational commitment $(B=0.657, t=$ $15.794, p<0.05)$ as the regression model was found to be Organizational Commitment $(Y)=1,14+0,66 *$ Job Satisfaction (X). Another significant finding was that $52 \%$ of the total variance related to the organizational commitment of the employees was explained by the job satisfaction variable. In simple regression analysis, this effect level obtained with a single independent variable was high, showing that organizational commitment is a crucial factor on job satisfaction.

The study also revealed that as job satisfaction levels increase, healthcare employees tended to perceive their work as safer. As job satisfaction is one of the primary factors that motivate an individual towards productivity, individuals with high level of job satisfaction are more productive at work and contribute to greater profitability in hospital.

The managers should make most of the experiences of senior workers as well as the creative, idealist and innovative approaches of younger generations. In the process of decision-making, the employers should take into account of Generation Y workers' opinions and views with an 
aim to increase their job satisfaction and organizational commitment. Arrangements should be made for sport, excursions and cultural activities for those Generation $Y$ workers who wish to spend time for social activities outside of work. In addition, considering that the perception of job satisfaction increases together with the socio-economic levels of the employees, employers should not forget that the financial and moral support, such as increase in wages, financial awards, advances, bonuses etc., provided to employees is likely to increase their job satisfaction.

To this end, similar studies have been conducted on different samples and profiles of healthcare employees. These studies have produced similar results to our study. For example, Gemlik, Ilter and Bektas (2018) assessed the expectations of Generation $Y$ managers in a public hospital in Istanbul (23). The participants also expressed a preference for a workplace that is fair, just and motivating and superiors who share their experience with them. Moreover, factors such as innovation, opportunities for self-development, respect from others, opportunities to participate or give opinions during decision-making processes, approval by and support from superiors were included among their preferences (23).

Similarly, Sencan, Aydintan and Yegenoglu (2017) found a significant and positive relationship between organizational commitment and job satisfaction of managers in a survey conducted on 98 executives that work in pharmaceutical companies (24). In other words, the study observed that as organizational commitment increases along with an increase in job satisfaction (24). With respect to levels of job satisfaction among nurses in a state hospital in Turkey, Tilev and Beydağ (2014) reported that job satisfaction levels differed according to the units and working hours of nurses, while job satisfaction did not differ according to age or gender (25). In Top's study (2012) in five state teaching and research hospitals in Istanbul on 304 physicians ( $12.54 \%$ of total physicians) and 254 nurses (15.38\% of total nurses), a strong and significantly positive relationships was found between organizational commitment, job satisfaction and organizational trust physicians and nurses (26).

Regarding the organizational commitment and job satisfaction levels of nurses and medical secretaries, Gider, Simsek, Ocak and Top (2011) observed that both job satisfaction levels of nurses and medical secretaries differ significantly according to their profession, income status and the type of hospitals (27). In addition, the study detected a statistical relationship between job satisfaction and the total working years in the hospital (27). Lastly, a significant relationship was found between the job satisfaction perceived by nurses and medical secretaries and their organizational commitment $(r=0.597, p=0.000 ; p<0.005)(27)$.

Lastly, Karahan (2008) conducted a study on 321 healthcare workers with different job titles in Afyonkarahisar State Hospital in order to determine whether the leadership characteristics of managers exert any influence on the organizational commitment of the employees in hospitals (28). The study confirmed the existence of significant relationships between leadership type and organizational commitment and found that the factor of leadership effects the levels of organizational commitment among the workers in a positive manner (28). Likewise, Tengilimoğlu and Yiğit (2005), in their study on the effects of leadership behaviours on job satisfaction of 355 medical professionals working at Tokat Cevdet Aykan State Hospital, determined that four types of leadership styles had a positive effect on job satisfaction (29).

The main limitation in the present study was caused by the design of the model, namely the study was limited to a single dependent variable and it solely examined the relationship between job satisfaction and organizational commitment. The results of the present study can be supported with different samples, studies, and models looking at different organizational dynamics in order to increase the generalizability of the results. Moreover, the impact of organizational commitment on job satisfaction could be studied, as well as specific indicators and their effects on job satisfaction and organizational commitment.

It is vital for hospital administrators and managers to put in place systematic reviews for the assessment levels of job satisfaction and organizational commitment of their employees. In addition, they should acknowledge the need for developing specific and effective strategies to improve the perceptions of incoming Generation Y employees. As this study demonstrated, the concepts of job satisfaction and organizational commitment are intrinsically related to and impacted by issues such as the opportunities for participation in decision making processes, transparent and fair leadership, employee needs, employee support and encouragement and leadership styles. As shown, researchers have made persuasive arguments showing that high level of job satisfaction leads to high level of organizational performance, and it helps to improve hospital's performance, profitability and the quality of patient care. 


\section{Conclusions}

This study showed a strong and positive relationship between job satisfaction and organizational commitment among Generational $Y$ healthcare employees in Turkey. The results were in line with previous studies conducted on other groups of healthcare professions. The productivity and effectiveness of inter-generational teams depend on a closer understanding of expectations and values of each generation. The needs of Generation $Y$ healthcare employees include the opportunities for selfdevelopment, participation in the decision-making processes, wish to be respected and inclusion in mechanisms allowing for intergenerational experience and skills sharing and frequent feedback. These characteristics should be taken into account by management for the purposes of maintaining a high level of job satisfaction and organizational commitment and a high hospital performance.

\section{References}

1. Eris ED, Sural Ozer P, Timurcanday Ozmen ON, Cakir O, Tozkoparan G. Generation Y in Turkish Context: Multiple Foci Research. International Journal of Business and Management Studies. 2013; 5(1): 150-161.

2. Kraus M. Comparing Generation $X$ and Generation $Y$ on their Preferred Emotional Leadership Style. Journal of Applied Leadership and Management. 2017; 5: 62-75.

3. Sigri U, Basim N. An Analysis of Employees' Levels of Job Satisfaction and Organizational Commitment: A Comparative Research in Public and Private Sector (in Turkish). SÜ iiBF Sosyal ve Ekonomik Araştırmala Dergisi. 2006; 6(12): 131-154.

4. Kacmar MK, Carlson DS, Brymer RA. Antecedents and Consequences of Organizational Commitment: A Comparison of Two Scales. Educational \& Psychological Measurement. 1999; 59(6): 976-994.

5. Carmeli A, Freund A. Work Commitment, Job Satisfaction and Job Performance: An Emperical Investigation. International Journal of Organization Theory and Behavior. 2004; 7(3): 289-303.

6. Hajdukova A, Klementova J, Klementova J. The job satisfaction as a regulator of the working behaviour. Procedia - Social and Behavioral Sciences. 2015; 190: 471-476.

7. Locke EA. The nature and causes of job satisfaction. In MD Dunnette (Ed), Handbook of industrial and organizational psychology. Chicago: Rand McNally,1967: 1297-1343.

8. Hulin CL, Judge TA. Job Attitudes. In WC Borman, DR Ilgen, RJ Klimoski (Eds), Handbook of psychology: Industrial and organizational psychology. Hoboken, NJ:Wiley;2003: 233-250.

9. Judge TA, Klinger R. Job satisfaction: Subjective well-being at work. M Eid \& RJ Larsen (Eds), The science of subjective well-being. Guilford Press; 2008: 393-413.

10. Tengilimoğlu D. A Study on the Relationship Between Leadership Approaches and Job Satisfaction (in Turkish). TicaretveTurizmEğitimFakültesiDergisi. 2005; (1): 23-45.

11. Koç M, Öztürk L, Yıldırım A. A Study on Job Satisfaction and Organizational Commitment of Generations $X$ and $Y$ (in Turkish). Research Journal of Business and Management. 2016; 3(2): 173-183.

12. Koç H. Relationship Between Organizational Commitment and Loyalty (in Turkish). Elektronik Sosyal Bilimler Dergisi. 2009; 8(28): 200-211.
13. Ford R, Sivo S, Fottler M, Dickson D, Bradley K, Johnson L. Aligning Internal Organizational Factors with a Service Excellence Mission: An Exploratory Investigation in Healthcare. Health Care Management Review. 2006; 31(4): 259-269.

14. Shouksmith G. Variables Related to Organizational Commitment in Health Professionals. Psychology Report. 1994; 74(3): 707-711.

15. Tanner BM. An Analysis of The Relationships Among Job Satisfaction, Organizational Trust, and Organizational Commitment in An Acute Care Hospital. Unpublished Ph.D. dissertation, Faculty of Saybrook Graduate School and Research Center, San Francisco, CA; 2007.

16. Torun $Y$, Çetin C. Evaluation of Organizational Cynicism on a Generational Basis (in Turkish). İş ve Insan Dergisi. 2015; 2(2): 137-146.

17. Türker N, Öztürk I. Job Satisfaction and Organizational Commitments of Execution Protection Officers: An Example in Western Black Sea Division (in Turkish). Karabük Üniversitesi Sosyal Bilimler Enstitüsü Dergisi. 2016; 2: 56-78.

18. Aydogmus C. How to Satisfy Generation Y? The Roles of Personality and Emotional Intelligence. International Review of Management and Business Research. 2016; 5(4): 1342-1358.

19. Gürbüz S. Intergenerational Differences: A myth or reality? (in Turkish). İ̧ ve İnsan Dergisi. 2015; 2(1): 39-57.

20. Saracel N, Taşseven Ö, Kaynak E. Relationship of Job Satisfaction and Motivation in Generation Y Workers in Turkey (in Turkish). Social Sciences Research Journal. 2016; 5(1): 50-79.

21. Meyer JP, Allen N. Commitment to Organizations and Occupations: Extension and Test of a Three-Component Conceptualization. Journal of Applied Psychology. 1993; 78(4): 538-551.

22. Weiss DJ, Dawis RV, England GW, Lofquist LH. Manual for the Minnesota SatisfactionQuestionnaire. Minnesota Studies in VocationalRehabilitation, Minneapolis: University of Minnesota, Industrial Relations Center; 1967: 22.

23. Gemlik N, İlter P, Bektaş G. A QualitativeResearch on theExpectations of Generation Y HospitalManagers (in Turkish). Sağlık Akademisi Dergisi. 2018; 5(2): 154-160.

24. Şencan NS, Aydıntan B, Yeğenoğlu S. A Research Aimed at The Organizational Commitment and Job Satisfaction Of Managers Working in Turkish Drug Industry (in Turkish). Gazi İktisat ve Işletme Dergisi. 2017; 3(2): 117-148.

25. Tilev S, Beydağ K. Level of Job Satisfaction Among Nurses (in Turkish). Sağlık ve Hemşirelik Yönetim Dergisi. 2014; 1(3): 140-147.

26. Top M. The profile of physicians' and nurses' organizational commitment, organizational trust and job satisfaction (in Turkish). İstanbul Üniversitesi İşletme Fakültesi Dergisi. 2012; 41(2): 258-277.

27. Gider Ö, Şimşek G, Ocak S, Top M. Analysis of Organizational Commitment and Job Satisfaction in Hospital Organizations: A Study Based on Nurses And Medical Secretaries (in Turkish). Öneri Dergisi. 2011; 9(35): 93-101.

28. Karahan A. A Research on Analyzing Relationship Between Leadership And Organizational Commitment In Turkey's Hospitals (in Turkish). Afyon Kocatepe Üniversitesi Sosyal Bilimler Dergisi. 2008; 10(1): 145-162.

29. Tengilimoğlu D, Yiğit A. Determining the Effects of Leadership Behaviors on the JobSatisfaction of Personnel in Hospitals: A Field Study (in Turkish). Hacettepe Sağlık İdaresi Dergisi. 2005; 8(3): 374-400. 